Section Head: SCUDDER ORATION ON TRAUMA

\title{
Vascular Trauma Revisited
}

David V Feliciano ${ }^{1-4}$, MD, FACS

${ }^{1}$ Clinical Professor of Surgery, University of Maryland School of Medicine, Baltimore, MD

${ }^{2}$ Attending Surgeon, Shock Trauma Center, University of Maryland Medical Center, Baltimore, MD

${ }^{3}$ Battersby Professor of Surgery Emeritus, Indiana University, Indianapolis, IN

${ }^{4}$ Chief Emeritus, Division of General Surgery, Indiana University School of Medicine, Indianapolis, IN

\section{Disclosure Information: Nothing to disclose.}

Presented at the American College of Surgeons 96th Annual Clinical Congress, Washington, DC, October 2010.

Corresponding Author Address:

David V Feliciano, MD, FACS

640 South River Landing Road

Edgewater, Maryland 21037

Cell - 404-550-3506

Email - davidfelicianomd@gmail.com

Running Head: Vascular Trauma

This is the author's manuscript of the article published in final edited form as:

Feliciano, D. V. (2017). Vascular Trauma Revisited. Journal of the American College of Surgeons. https://doi.org/10.1016/j.jamcollsurg.2017.08.011 


\section{INTRODUCTION}

Trauma with bleeding from named vessels has been treated since antiquity. Many of the techniques used in the modern era to control bleeding such as manual compression, cauterization, and proximal and distal ligatures were described before 1000 AD. Even the earliest version of a hemostat, Ambrose Pare's "Bec de Corbin", was described in the 1500s.

With the exception of case reports of vascular repair in 1759,1762 , and 1882 , all progress in the clinical repair of injured vessels has been made in the past 117 years. Extraordinary advances in the techniques of operative repair were made in World War I, the Korean War, and the Vietnam War by military surgeons. The significant increase in civilian urban trauma from penetrating wounds since the 1960s in the United States has been a major factor in the advances in vascular repair developed by civilian trauma surgeons. These advances have included the following: (1) return of tourniquets to control bleeding from an extremity; (2) improved techniques of resuscitation with blood; (3) recognition of the value of a physical examination and an arterial pressure index to detect a peripheral vascular injury; (4) the availability of duplex ultrasonography and CT-arteriography (CTA); (5) improved techniques for retrieval of the greater saphenous vein; (6) availability of polytetrafluoroethylene grafts; (7) innovative approaches such as balloon catheter tamponade, use of a temporary intraluminal shunt, and an extraanatomic bypass; and (8) earlier recognition of compartment syndromes in injured extremities.

Even with all these operative advances and the availability of endovascular techniques, patients still present with complex vascular lesions that challenge the modern trauma vascular team. 
The presence of a vascular injury in any trauma patient has a significant impact on subsequent management and outcome. With a "hard" sign of a vascular injury such as external hemorrhage, a rapidly expanding hematoma, palpable thrill/audible bruit, or the " $6 \mathrm{P}$ 's" of arterial occlusion in an extremity (pulselessness, pallor, paresthesias, pain, paralysis, poikilothermia), control of hemorrhage and restoration of flow are the priorities. ${ }^{1,2}$ The sequencing and timing of these will then depend on the patient's physiologic status and presence of associated injuries.

This review will discuss the following: (1) history of the control of hemorrhage; (2) abbreviated chronological review of the management of vascular trauma since the early $20^{\text {th }}$ century; and (3) case-based management of vascular trauma in the modern era.

\section{CONTROL OF HEMORRHAGE}

Aulus Cornelius Celsus (25 BC - 50 AD), thought to be a nobleman in Rome, authored the first textbook (18 volumes) of medicine and surgery known as De Medicina. ${ }^{3}$ This text summarized medical knowledge from "Hippocrates to the beginning of the Christian era," but was ignored for 13 centuries till rediscovered by Pope Nicholas V in 1433 and then printed in $1476 .^{3,4}$ In the section on wounds caused by trauma in which pressure did not control hemorrhage, he recommended the following: "the bleeding vessels should be taken up, and ligatures having been applied above and below the wounded part, the vessels are to be divided in the interspace...,3

Galen of Pergamum (129-199 AD) in Asia Minor is considered by medical historian Ira M. Rutkow to be "second only to Hippocrates as the most important physician of all antiquity." This is based on the extraordinary volume of his medical writings during his time in Pergamum 
and for the majority of his career spent in Rome. Many of his observations and conclusions were in error, but his writings dominated Western medicine for the next 15 centuries. Galen had extensive experience as a "trauma surgeon", having served as a surgeon to the gladiators for four years in Pergamum. His comment on how to control hemorrhage was "by placing a finger on the orifice of a bleeding superficial vessel.",4,5

Antyllus (second century AD) is described as the "first vascular surgeon", but evidently had experience with a variety of operations in neurosurgery (hydrocephalus), ophthalmology (cataracts), and in performing tracheostomies. ${ }^{4}$ In operating on a patient with rupture of a superficial aneurysm, he first applied finger pressure to the area of hemorrhage. Then "we pass underneath the isolated part the needle with the double thread" and proximal and distal ligation was performed. ${ }^{4}$

Albucasis or Abul Quasim (936-1013) practiced as a physician and surgeon in Muslim Spain (Western Caliphate). His Altasrif was a collection of 30 manuscripts, three of which dealt with surgery. Rutkow states that "the Altasrif became the leading authority on surgery in the Middle Ages". 6 In the section on "Cauterization in Arterial Hemorrhage" (Book I, Chapter 56, pp 56-57), Albucasis describes four methods of controlling hemorrhage as follows: (1) "by cauterization"; (2) "by division of the artery"; (3) "by firm ligature"; and (4) "by the application of remedies". ${ }^{7}$

Ambroise Pare (1510-1590) of France is considered the father of modern surgery, despite the fact that he was only a "master barber-surgeon." He is one of the most famous military surgeons in history (see Battle of Turin, 1536) and was chief surgeon to four consecutive kings of France. ${ }^{8,9}$ Pare wrote extensively about the control of hemorrhage, particularly during amputations performed during military conflicts. One of his major contributions in this area was 
to design an instrument known as the "Crowes beake" ("Bec de Corbin"). ${ }^{10}$ This curved grasping instrument, looking much like a modern hemostat, was used to grasp actively bleeding vessels that had retracted from view.

Sir Thomas Spencer Wells (1818-1897) served in the British military during the Crimean War, where he gained experience in laparotomies. He subsequently became a famous private surgeon in London with a large practice in ovariotomies, for which he developed the modern hemostat (Spencer-Wells clamp) ${ }^{11}$ Wells wrote a two-volume text entitled Diseases of the Ovaries and became President of the Royal College of Surgeons in 1881.

\section{MANAGEMENT OF VASCULAR TRAUMA - ABBREVIATED CHRONOLOGICAL}

\section{REVIEWS SINCE THE EARLY $20{ }^{\mathrm{TH}}$ CENTURY}

The history of early attempts at vascular surgery and repairs after vascular trauma has been well-described by Norman M. Rich, MD in numerous publications and chapters. ${ }^{12-15}$ Modeled on the chronological lists of contributors/contributions in several of Rich's publications, ${ }^{12,14}$ two comprehensive Tables on the history of the management of vascular trauma since the early $20^{\text {th }}$ Century are included as part of this review (Table 1. Military ${ }^{16-45}$; Table 2. Civilian $\left.^{46-88}\right)$.

\section{MANAGEMENT OF VASCULAR TRAUMA - A CASE-BASED REVIEW}

\section{Missed Diagnosis of Arterial Injury}

A 22-year old man was stabbed in the proximal right leg. Emergency medical services personnel reported that there was obvious blood on the rug of the living room where the injury occurred. On examination in the emergency center of a Level I trauma center, a 1.5-cm stab wound was noted on the medial right calf approximately $10-\mathrm{cm}$ distal to the knee joint. There 
was no bleeding from the wound, no palpable hematoma, and the dorsalis pedis pulse was readily palpable on the right foot. The right posterior tibial artery was present by palpation, but diminished as compared to the dorsalis pedis pulse. It was decided that the absence of active hemorrhage or an expanding hematoma and the presence of palpable right pedal pulses ruled out the possibility of an arterial injury. No ankle-brachial-index nor arterial pressure index was measured, and no vascular imaging was performed. ${ }^{70-71}$ The patient was not given any specific instructions other than to return if he had any "problems".

Three weeks later, the patient returned to the emergency center with a complaint of swelling of the right leg. The surgical team noted that the proximal right leg was "pulsatile", that the dorsalis pedis pulse was readily palpable, and that the posterior tibial pulse was audible with a Doppler device. An urgent arteriogram (this patient was treated prior to the availability of CT arteriography) documented the presence of an $8-\mathrm{cm}$ diameter traumatic false aneurysm of the right tibioperoneal trunk approximately $4-\mathrm{cm}$ distal to the origin of the right anterior tibial artery. At operation through a right medial distal popliteal incision, a large pulsatile firm traumatic false aneurysm arising from the right tibioperoneal trunk was present. The tibioperoneal trunk was controlled above the traumatic false aneurysm, which was then opened and evacuated. The orifices of the posterior tibial and peroneal arteries could not be identified in the aneurysm sac, but some small areas of back-bleeding were oversewn. After ligation of the proximal tibioperoneal trunk, the right foot continued to have a palpable dorsalis pedis pulse and continued to be pink and warm.

Comment - The list of physician errors in the management of this patient is impressive. External bleeding is strongly suggestive of a vascular injury, as was the diminished posterior tibial pulse. ${ }^{1}$ Based on these, an ankle-brachial index or arterial pressure index (Doppler-derived) at the right 
posterior tibial artery would have surely been $<0.9 .^{70,71}$ This would prompt a CTA in the modern era.

As most missed arterial injuries in the extremities are symptomatic within 10 days, the patient should have been given clear instructions ("the leg should improve, not worsen") and follow-up clinic appointments at one week, two weeks, and two months. ${ }^{89}$

\section{Preoperative Arteriography despite "Hard" Signs of Arterial Injury}

A 23-year old man presented to the emergency center after suffering a close range shotgun wound to the medial right thigh. There was a defect in soft tissue at the mid-thigh, pellet holes covered the inferior $2 / 3$ of the thigh, and the ankle-brachial index at the right foot was $<0.9$. The surgical resident team felt that the patient had enough signs of a major arterial injury in the thigh (large soft tissue defect over usual course of superficial femoral artery and the femoral vein, diminished pedal pulse, multiple pellets in proximity to the femoral vessels) to justify an emergency operation. The attending surgeon pointed out that the patient did not have significant external bleeding and that there was arterial flow to the right foot. In addition, he reminded the team that a blind exploration to encompass the area of pellets in proximity to the vessels would involve one-half of the length of the patient's thigh. A formal arteriogram in interventional radiology documented the presence of six clear-cut defects in an $8-\mathrm{cm}$ segment of the left superficial femoral artery. The segment containing the defects was resected, and a reverse autogenous saphenous vein graft from the right groin was inserted as an interposition graft into the superficial femoral artery. Several small venorrhaphies were performed in the femoral vein in the same area. The sartorius muscle covered the saphenous vein graft well, and the 5-cm skin defect in mid-incision was allowed to granulate till a split-thickness skin graft was applied. 
Comment - This patient had a combination of the previously described "hard" (diminished distal flow) and "soft" (proximity of wound to a named artery) signs of an arterial injury in an extremity. ${ }^{1,2}$ There was a strong temptation to perform an emergent operation due to these signs and to the dramatic presentation (large skin defect from close-range shotgun wound, wide dispersal of pellets). There are, however, several clinical scenarios in patients with "hard" signs of an arterial injury in the neck or an extremity (other than external bleeding) in which a preoperative CTA or duplex ultrasonography may be very helpful to the trauma vascular surgeon. These are listed as follows: (1) wound in the thoracic inlet; (2) shotgun wound to an extremity; and (3) segmental fractures or fractures at two levels in an extremity. ${ }^{90}$ In each of these complex scenarios, the imaging study will be useful in documenting the presence and location of an arterial injury and in planning the location and length of incision at operation.

\section{Missed Arterial Injury at Operation}

A 21-year old man presented to the emergency center with a gunshot wound to the left lateral pectoralis major muscle. He was hemodynamically stable, the exit wound was in the left upper back, and the left radial pulse was normal. There was some swelling of the left axilla, but this was difficult to assess because of the patient's muscular habitus. A formal arteriogram was performed and demonstrated a defect in the left mid-axillary artery. An inexperienced surgical team explored the patient through a left infraclavicular incision extending to the most proximal medial left arm. There was some blood staining of the tissues, but the third portion of the left axillary artery (lateral to the pectoralis minor muscle) was exposed and found to be without an injury. The pectoralis minor muscle was then elevated with a Richardson retractor. This aided in the dissection of the lateral aspect of the second portion of the left axillary artery (behind pectoralis minor muscle). Again, no arterial injury was noted in this area. A decision was reached 
by the surgical team that the arteriogram must have been a "false-positive." The incision was closed, and the patient was discharged on the second postoperative day.

Three weeks later, the patient returned to the emergency center with a complaint of swelling of the left upper chest and axilla. The surgical team confirmed that this entire area was swollen and noted the presence of a palpable thrill in the left axilla, as well. An urgent arteriogram documented the presence of a massive traumatic false aneurysm of the mid-left axillary artery with an associated arteriovenous fistula (Figure 1). In the era before the availability of endovascular stent grafts, an autogenous saphenous vein graft was used to replace the injured segment of left axillary artery at a reoperation. A left axillary venorrhaphy was performed, as well.

Comment - The obvious error with management was the failure to fully expose the area of probable injury to the left axillary artery. The original surgical team chose to enter the left axilla through the intermuscular groove between the pectoralis major and deltoid muscles, carefully avoiding the cephalic vein. This incision provides excellent access to the third portion of the axillary artery as noted above. The second portion, however, is difficult to visualize in a muscular individual by manual elevation of the pectoralis minor muscle alone. The tendon of this muscle on the coracoid process of the superior scapula should have been divided while preserving the medial pectoral nerve for complete exposure. ${ }^{91}$ Trauma surgeons do not make any attempt to reattach this tendon at the completion of the vascular repair.

Because the deltopectoral approach can be somewhat tedious and difficult in a patient with bleeding from the first or second portion of the axillary artery, transverse division of the fibers of the overlying pectoralis major muscle is another approach. Again, transection of the 
tendon of the pectoralis minor muscle will be necessary to expose the second portion and, if desired, the first portion of the axillary artery.

For the inexperienced trauma surgeon confronted with exsanguinating hemorrhage from either the first or second portions of the axillary artery, there is still another rarely utilized approach. This is division of the tendon of the pectoralis major muscle from the crest of the intertubercular groove of the humerus. The tendon is divided at least $1.5-2 \mathrm{~cm}$ from the humerus to allow for reattachment of the tendon at the completion of the vascular repair.

The second error made in intraoperative management of this patient was the failure to perform an arteriogram to localize the "missing" injury. A Cournand disposable arteriogram needle should have been inserted into the third portion of the left axillary artery with the tip facing medially. After the application of a blood pressure cuff inflated to $300 \mathrm{~mm} \mathrm{Hg}$ on the left arm, a retrograde injection of radiologic contrast under fluoroscopy would then be performed. ${ }^{92}$ This technique will visualize the proximal axillary-subclavian arterial system with all its major branches and would have demonstrated the area of injury in this patient.

\section{Balloon Catheter Tamponade $\mathbf{x} 2$ for Bleeding at Base of Skull}

A 37-year old man was stabbed through the left eardrum by his brother. Pulsatile arterial flow was noted immediately, and another brother placed his right index finger into the left external auditory canal to control the bleeding. Upon arrival in the emergency center, a surgical resident's finger replaced that of the patient's brother. In the operating room, an 18-Fr. Foley balloon catheter was advanced into the patient's stab wound track. This was sequentially inflated till there was reasonable control of arterial hemorrhage. Any slight movement of the Foley balloon catheter, however, led to recurrent bleeding from the left ear. The surgical team then 
made a left oblique cervical incision and exposed the proximal left internal carotid artery. Through a pursestring 6-0 polypropylene suture, a small arteriotomy was made in the proximal left internal carotid artery. A \#4 Fogarty balloon catheter (Edwards Lifesciences, Irvine, CA) was inserted through the arteriotomy, advanced superiorly, and sequentially inflated till all arterial bleeding from the left ear stopped. (Figure 2).

Comment - The internal carotid artery inferior to the base of the skull cannot be exposed quickly because of the overlying mandible. Should external bleeding occur from a penetrating wound in high Zone II or Zone III of the neck, local compression would be the first step in management. ${ }^{93}$ Rapid transfer to the operating room for a vertical ramus osteotomy of the mandible or subluxation of the temporomandibular joint and interdental wiring or interarch fixation in edentulous patients is then performed to expose the internal carotid artery. ${ }^{94-96}$

In the patient described, the volume of arterial bleeding was impressive and packing of the external auditory canal was unlikely to control this. The failure of the Foley balloon catheter to completely control hemorrhage prompted the insertion of a trans-arterial Fogarty balloon catheter, as well -the only time in the author's career in which two separate balloons were needed to control hemorrhage from one artery.

Once bleeding is controlled by the balloon catheter, a decision must be reached on whether to expose the injured internal carotid artery and repair it, call an endovascular surgeon for insertion of a stent-graft, or to allow for thrombosis to occur around the balloon in the artery. An immediate transfer to radiology for a contrast-enhanced CT of the brain is useful to document whether ischemia of the hemibrain is occurring. Also, a CTA will demonstrate the amount of crossover flow from the contralateral carotid and vertebral artery systems. If crossover flow is adequate, every effort is made to maintain the patient's oxygenation and blood pressure and 
minimize edema of the hemibrain on the side of the balloon in the intensive care unit. A return to the operating room in 48 hours for removal of the balloon catheter under direct vision is appropriate if the patient has done well. A patient with inadequate crossover flow will need insertion of an endovascular stent-graft or immediate reconstruction of the injured carotid artery with the aid of a "skull base" surgery team. ${ }^{97}$

All trauma and vascular surgeons are aware of the multiple other locations in which balloon catheter tamponade can be used to control hemorrhage. ${ }^{55,56,59,98}$

\section{Temporary Intraluminal Vascular Shunt}

A 58-year old woman standing in a parking lot had her right knee and proximal leg crushed between the bumpers of two cars. Upon arrival in a Level I trauma center, her systolic blood pressure was $70 \mathrm{~mm} \mathrm{Hg}$, temperature $35^{\circ} \mathrm{C}$ and arterial $\mathrm{pH}$ 7.2. In addition, there was bleeding from a proximal medial laceration of the right leg. A rapid physical examination and xrays in the emergency room documented a pulseless right foot that was sensate and that had motor function, an open dislocation of the right knee, and a mid-shaft fracture of the tibia. Operative findings were transection of the distal right popliteal artery and vein, avulsion of the anterior tibial artery and vein, and the joint-bony injuries as described. Once the ends of the popliteal artery and vein were isolated, \#12 Fr Argyle (Medtronic, Minneapolis, MN) carotid artery shunts were inserted to reestablish arterial inflow and venous outflow. The transected ends of the anterior tibial artery and vein were ligated. The orthopedic trauma service then scrubbed in, inserted an intramedullary rod into the fractured tibia and relocated the right knee joint. Upon completion of the orthopedic procedure, the trauma team scrubbed back in. The patient was hemodynamically stable with a body temperature of $36^{\circ} \mathrm{C}$, and a decision was reached to complete vascular reconstruction at that time. Autogenous saphenous vein interposition grafts 
retrieved from the left uninjured thigh were then inserted into the popliteal artery and vein after removal of the shunts. Debridement of frayed and ischemic muscle tissue in the proximal medial superficial posterior muscle compartment of the leg was performed before closure of much of the medial skin wound/incision. Finally, a fasciotomy of the anterior and peroneal muscle compartments of the right leg was performed. Total operative time was nine hours, while blood replacement was 12 units packed red blood cells. The patient underwent seven more operations for debridements, bleeding from granulation tissue, and application of split-thickness skin grafts to the anterior-peroneal compartment fasciotomy site and medial popliteal wound. She was discharged 38 days after injury. When seen three years later, she had a normal gait, but used a cane for "support." Her major complaint was "aching" in the right knee and leg when the "weather changed."

Comments - Much has been written about temporary intraluminal vascular shunts in recent

years. ${ }^{42,99-101}$ There are at least seven indications for a shunt as outlined in Table $3 .{ }^{100}$ In the modern era shunts are inserted in up to $9 \%$ of patients with vascular injuries in civilian reviews. ${ }^{99}$ Of interest, the most common indications continue to be a Gustilo IIIC open fracture in an extremity and need for a "damage control" operation.

In the patient described, both classical indications were present. The shunt preserved viability of the right leg and foot during orthopedic reconstruction and as hypotension, hypothermia, and a metabolic acidosis were corrected.

\section{Use of Ringed PTFE Graft in Peripheral Vein}

A 21-year old man was shot in the distal left thigh and presented with a large medial hematoma and a pulseless left foot. In the operating room, the distal left superficial femoral 
artery and the femoral vein were $80 \%$ transected with jagged open ends. After proximal and distal vascular control of both vessels was obtained, the jagged ends were debrided resulting in a 3.5-cm defect in each vessel. An autogenous reversed saphenous vein graft from the right groin was inserted as an interposition graft into the superficial femoral artery. It was obvious that the saphenous vein was too small to be inserted as an interposition graft into the left femoral vein. Based on the author's previous tedious and unhappy experiences in creating either a spiral vein graft or a venous panel graft, a 10-mm ringed PTFE graft was inserted as an interposition graft into the left femoral vein (Figure 3). A venogram of the injured extremity at two weeks after injury documented normal flow through the left femoral vein in the thigh. The patient was advised to continue elevation of the left lower extremity when supine, cessation of smoking, ingestion of a "baby aspirin" every 12 hours for three months, and a daily walking program.

Comment - Repair versus ligation of major injured veins in the lower extremities continues to be a controversial topic. There are significant military and some civilian data documenting the beneficial impact of venous repair on the adjacent arterial repair and in avoiding the need for below knee fasciotomy and long-term venous sequelae in the injured lower extremity. ${ }^{102-107}$ In contrast, there are primarily civilian reports documenting only modest sequelae after ligation of the popliteal, femoral, or common femoral vein in the lower extremity. ${ }^{108-111}$

The recent extensive experience with the use of temporary intraluminal vascular shunts in both military and civilian vascular injuries has convinced the author that ligation of a major vein in the lower extremity is no longer appropriate. And, with the extended time necessary to construct a spiral or panel vein graft, a ringed PTFE interposition graft is an appropriate second choice to the greater saphenous vein. Patency of 42 venous repairs by venography or duplex ultrasonography in one civilian series at a mean of $10.9 \pm$ days after repair was as follows: 
primary repair $76.5 \%$; autogenous vein graft $66.7 \%$; PTFE graft $73.7 \% .^{107}$ If one follows PTFE venous interposition grafts long-term, there is gradual deposition of pseudointima and/or peripheral clot so that thrombosis occurs gradually...if it is to occur. This allows for the gradual development of venous collaterals.

\section{Value of Extra-anatomic Bypass to Treat Postoperative Blowout of Arterial Repair}

A 23-year old had a 6-mm PTFE graft inserted into the right brachial artery following a gunshot wound to the distal arm. ${ }^{112}$ The operative note described an "inadequate" greater saphenous vein in the right groin. Unfortunately, there was extensive loss of soft tissue over the PFTE graft. The surgical team chose to cover the exposed graft with Vaseline Petrolatum Gauze Dressing (Emergency Safety Supply LLC, Harrisburg, OR) under antibiotic-soaked gauze. On the fourth postoperative day, arterial bleeding was noted to be coming from a partial dehiscence of the proximal PTFE-brachial artery suture line. The patient was returned to the operating room, and the PFTE graft was removed. After exposing healthy proximal and distal brachial artery, a medially placed extraanatomic interposition graft with autogenous saphenous vein was inserted. Both suture lines were covered by healthy tissue after the small incisions proximal and distal to the defect in soft tissue were closed. The defect in soft tissue was treated with wet-to-dry dressings until a split-thickness skin graft was applied on the $11^{\text {th }}$ post-trauma day. At the time of long-term follow-up at 22 months, the patient had normal right radial and ulnar pulses and full range of motion of the right elbow (Figure 4).

Comment - The indications for performing an extraanatomic vascular bypass in an injured extremity are listed in Table $4 .{ }^{112-114}$ 
While the technique appears somewhat formidable to inexperienced trauma vascular surgeons, the steps in performing the operation are straightforward. First, systemic heparinization with 100 units/kg is initiated. The exposure of healthy proximal and distal artery and/or vein usually mandates separate longitudinal incisions over the vessels outside the area of injury or infection. It is best to mark the saphenous vein or ringed PTFE graft with a straight line to avoid twisting of the graft through the extraanatomic tunnel. The extraanatomic tunnel through subcutaneous or muscle tissue is created with a large biliary Bakes dilator. With an adequate tunnel in a gentle curve, the reversed and marked autogenous saphenous vein and/or PTFE graft is pulled through the tunnel in a collapsed fashion. After the proximal healthy artery-to-graft anastomosis is created, flushing through the distal open end of the graft is performed to verify that the graft is not kinked in the tunnel. The proximal artery is reclamped and the area of the graft is compressed to evacuate blood from the entire graft. The graft is then trimmed to an appropriate length. As the distal graft-to-artery anastomosis is close to completion, proximal and distal flushing is performed. With arterial and/or venous flow restored, both graft-artery suture lines are covered by closing the separate longitudinal incisions mentioned above.

\section{Volar-Ulnar Fasciotomy of the Forearm}

A 44-year old bodybuilder had an injection of "steroids" into his right antecubital area by a colleague. Over the next three days, he noted progressive edema, erythema, and firmness of the right antecubital area. An emergency room physician in the patient's local hospital diagnosed “cellulitis" and prescribed "antibiotics". The patient's distal right arm, antecubital area, and proximal forearm worsened over the next two days. The patient returned to the local emergency room and was seen by the same physician. He told the patient he would need an "amputation". In addition, he was advised to go to a Level I trauma and acute care surgery center in the state 
capital. After evaluation by an attending surgeon at that center, a diagnosis of a necrotizing soft tissue infection was made. The pressure in the patient's superficial volar muscle compartment of the right forearm was measured and noted to be $25 \mathrm{~mm} \mathrm{Hg}$. After 12 hours of elevation of the entire right upper extremity in a sling and continued broad-spectrum antibiotics, the patient was reexamined. The patient's right hand was now swollen, and he complained of "tingling," as well. In the operating room, a right volar-ulnar forearm fasciotomy was performed. ${ }^{115}$ A transverse incision was made $1-\mathrm{cm}$ distal to the antecubital crease. At the ulnar edge of the volar forearm, the incision was extended in a right angle fashion (Figure 5). The remainder of the longitudinal volar fasciotomy incision extended down the ulnar side of the forearm with a gentle angle to end at the mid-aspect of the volar wrist. By elevation of the proximal right angle flap of skin and subcutaneous tissue proximally, the lateral compartment (mobile wad) muscles (brachioradialis, external carpi radialis longus and brevis) were decompressed. The superficial volar compartment was decompressed through a fasciotomy incision under the longitudinal skin incision. Finally, a space was created between the exposed flexor carpi ulnaris and flexor digitorum sublimis superficial muscles. Carefully avoiding the ulnar nerve and artery in this space, a longitudinal fasciotomy of the deep volar compartment was performed. No fasciotomy of the dorsal (extensor) compartment of the right forearm was felt to be necessary, either. An intraoperative consult with the Hand Service was obtained, but fasciotomy of the right hand was not felt to be necessary. The skin, soft tissue, and thrombosed veins in the area of the antecubital necrotizing soft tissue infection were extensively debrided.

After a longitudinal extension of the fasciotomy to decompress the distal right biceps muscle of the arm the following day, modest further debridement was necessary. Elevation of the entire right upper extremity and daily wet-to-dry dressing changes were performed for the next 
10 days. A split-thickness skin graft was then applied to the antecubital area and the volar forearm fasciotomy site.

Comment - The volar-ulnar technique to decompress the lateral, superficial volar, and deep volar compartments of the forearm is easy to remember and perform. It is, of course, the same technique used when a compartment syndrome occurs after injury to the subclavian, axillary, or brachial vessels.

The author performs fasciotomies based on the patient's history (especially if a delay in arterial repair), examination (massive swelling or neuromuscular dysfunction), and operative management (ligation of major vein in proximal extremity). To confirm the need for a fasciotomy, a compartment pressure of $>35 \mathrm{~mm} \mathrm{Hg}$ is a useful number to remembers as it exceeds the normal capillary pressure of $20-30 \mathrm{~mm} \mathrm{Hg}{ }^{62}$

\section{Arterial Bleeding in an Intravenous Drug Abuser}

A 25-year old woman with a known history of intravenous drug abuse (injections of heroin) presented to the emergency room with a recent history of pulsatile arterial bleeding from the left groin (Figure 6). A pressure dressing was applied and controlled the bleeding. The patient was questioned and admitted to repeated injections of heroin into the left femoral vein, presumably some of which caused the infected false aneurysm of the left common femoral artery. The pressure dressing was left in place for 24 hours with careful monitoring of the left pedal pulses, and intravenous broad-spectrum antibiotics were administered. The patient was taken to the operating room on the following day. The proximal left common femoral artery was encircled with a vessel loop by incising the inferior aspect of the left inguinal ligament for a distance of 2-cm. A separate longitudinal incision inferior to the false aneurysm allowed for 
exposure of the left superficial femoral artery. This, too, was encircled with a vessel loop. After intravenous heparin (100 units/kg) was administered, vascular clamps were applied to the encircled left common femoral and superficial femoral arteries. The mid- and distal left common femoral artery and the proximal superficial femoral and profunda femoris arteries were all infected. By careful elevation of the bifurcation of the common femoral artery, the profunda femoris artery beyond the area of infection was clamped, as well. The infected arteries and surrounding soft tissue were excised. The proximal healthy left common femoral artery was oversewn with two rows of 5-0 polypropylene suture and was noted to retract under the inguinal ligament. The healthy ends of the superficial femoral and profunda femoris arteries were elevated, another 2-cm was resected from each, and each was oversewn with two rows of 5-0 polypropylene suture. The open wound in the left groin was then packed with antibiotic-soaked gauze. The viability of the patient's left lower extremity was monitored in the intensive care unit for 48 hours. While the left leg and foot were cooler as compared to the right lower extremity, the extremity stayed viable. The patient's left groin was allowed to heal by secondary intention.

Comment - The misadventures of intravenous drug abusers in which arteries rather than veins are injected can result in infected false aneurysms. These have most commonly occurred in the brachial or common femoral arteries, but have been noted in the carotid artery, as well. ${ }^{116-118}$

The treatment of choice for infected false aneurysms of the groin is excision of the entire femoral artery system involved in the infection. ${ }^{119}$ Threatened viability of the involved lower extremity is extraordinarily rare, but is treated with an emergency obturator bypass to the superficial femoral artery. ${ }^{116-119}$ 


\section{REFERENCES}

1. Snyder WH, Thal ER, Bridges RA, et al. The validity of normal arteriography in penetrating trauma. Arch Surg 1978;113:424-428.

2. Yao J, Plant J, Wilson RF. Peripheral vascular injuries. In: Walt AJ, Wilson RF, eds. Management of Trauma. Pitfalls and Practice. Philadelphia: Lea \& Febiger; 1975:403419.

3. Celsus and the Alexandrians. In: Zimmerman LM, Veith I, eds. Great Ideas in the History of Surgery. Baltimore: Williams \& Wilkins; 1961:28-38.

4. The Classical World. In: Rutkow IM, ed. Surgery. An Illustrated History. St. Louis: Mosby; 1993:5-43.

5. Galen of Pergamum (129-199 AD). In: Zimmerman LM, Veith I, eds. Great Ideas in the History of Surgery. Baltimore: Williams \& Wilkins; 1961:39-55.

6. Islamic and Jewish surgery. In: Rutkow IM, ed. Surgery. An Illustrated History. St. Louis: Mosby; 1993:53-63.

7. Albucasis (Eleventh Century) and the surgery of the Arabic period. In: Zimmerman LM, Veith I, eds. Great Ideas in the History of Surgery. Baltimore: Williams \& Wilkins; 1961:81-89.

8. The Renaissance. In: Rutkow IM, ed. Surgery. An Illustrated History. St. Louis: Mosby; 1993:119-181.

9. Ambroise Pare (1510-1590). In: Zimmerman LM, Veith I, eds. Great Ideas in the History of Surgery. Baltimore: Williams \& Wilkins; 1961:179-192. 
10. Hurwitz A, Degenshein GA. Pare - Excerpts from The apologie and treatise, containing the voyages made into diverse places. In: Hurwitz A, Degenshein GA, eds. Milestones in Modern Surgery. New York City: Hoeber-Harper; 1958:6-17.

11. The Nineteenth Century. In: Rutkow IM, ed. Surgery. An Illustrated History. St. Louis: Mosby; 1993:321-503.

12. Rich NM. Vascular trauma. Surg Clin North Am 1973;53:1367-1392.

13. Rich NM, Leppaniemi A. Vascular trauma: a 40-year experience with extremity vascular emphasis. Scand J Surg 2002;91:109-126.

14. Rich NM. Historical and military aspects of vascular trauma with lifetime reflections of Doctor Norman Rich. In: Rich NM, Mattox KL, Hirshberg A, eds. Vascular Trauma. Second Edition. Philadelphia: Elsevier Saunders; 2004:3-72.

15. Rich NM, Walker AJ. The vascular injury legacy. In: Rasmussen IE, Tai NRM, eds. Rich's Vascular Trauma. $3^{\text {rd }}$ Edition. Philadelphia: Elsevier Saunders; 2016:3-12.

16. Soubbotich V. Military experiences of traumatic aneurysm. Lancet 1913.2:720-721.

17. Taylor DC. Two cases of penetrating wounds of the abdomen involving the inferior vena cava. Lancet 1916;2:60-61.

18. Shumacker HB Jr. Ramuald Weglowski: Neglected pioneer in vascular surgery. J Vasc Surg 1987;6:95-97.

19. Noszczyk W, Witkowski M. Romuald Weglowski. Polski Przeglad Chirurgiczny 1985;57:440-445. (Cited by Shumacker HB Jr. ${ }^{18}$ )

20. Makins GH. Gunshot injuries to the blood vessels. Bristol, England: John Wright and Sons Ltd; 1919. 
21. Blakemore AH, Lord JW Jr, Stefko PL. The severed primary artery in the war wounded. A nonsuture method of bridging arterial defects. Surgery 1942;12:488-508.

22. DeBakey ME, Simeone FA. Battle injuries of the arteries in World War II. An analysis of 2,471 cases. Ann Surg 1946;123:534-579.

23. Barr J, Cherry KJ, Rich NM. Vascular surgery in World War II. The shift to repairing arteries. Ann Surg 2016;263:615-620.

24. Elkin DC, Cooper FW Jr. Resection of the clavicle in vascular surgery. J Bone Joint Surg (Am) 1946;28:117-119.

25. Shumacker HB Jr. Operative exposure of the blood vessels in the superior anterior mediastinum. Ann Surg 1948;127:464-475.

26. Elkin DC, DeBakey ME. Vascular Surgery in World War II. Washington, DC: U.S. Government Printing Office; 1955.

27. Ziperman HH. Acute arterial injuries in the Korean War. A statistical study. Ann Surg 1954;139:1-8.

28. Hughes CW. Use of an intra-aortic balloon catheter tamponade for controlling intraabdominal hemorrhage in man. Surgery 1954;36:65-68.

29. Hughes CW. Arterial repair during the Korean War. Ann Surg 1958;147:555-561.

30. Spencer FC, Grewe RV. The management of arterial injuries in battle casualties. Ann Surg 1955;141:304-313.

31. Spencer FC. Historical vignette: the introduction of arterial repair into the US Marine Corps, US Naval Hospital, in July-August 1952. J Trauma 2006;60:906-909.

32. Howard JM. Battle casualties in Korea. Washington, DC: U.S. Government Printing Office; 1958. 
33. Howard JM. Historical vignettes of arterial repair. Recollections of Korea 1951-1953. Ann Surg 1998;228:716-718.

34. Rich NM, Hughes CW. Vietnam vascular registry: a preliminary report. Surgery $1969 ; 65: 218-226$.

35. Rich NM, Elster EA, Rasmussen TE. The Vietnam Vascular Registry: an historical perspective and continuing legacy. J Trauma Acute Care Surg 2017;83:S4-S8.

36. Hata KW, Propper B, Rich N. Fifty-year anniversary of the Vietnam Vascular Registry and a historic look at vascular registries. J Vasc Surg 2016;65:267-270.

37. Rich NM, Baugh JH, Hughes CW. Acute arterial injuries in Vietnam: 1,000 cases. J Trauma 1970;10:359-369.

38. Rich NM, Hobson RW II, Collins GJ Jr. Elective vascular reconstruction after trauma. Am J Surg 1975;130:712-719.

39. Rich NM, Hobson RW II, Collins GJ Jr. Traumatic arteriovenous fistulas and false aneurysms: a review of 558 lesions. Surgery 1975;78:817-828.

40. Rich NM, Spencer FC. Vascular Trauma. Philadelphia: WB Saunders; 1978

41. Eger M, Golcman L, Goldstein A, Hirsch M. The use of a temporary shunt in the management of arterial vascular injuries. Surg Gynecol Obstet 1971;132:67-70.

42. Rasmussen TE, Clouse WD, Jenkins DH, et al. The use of temporary vascular shunts as a damage control adjunct in the management of wartime vascular injury. J Trauma 2006;61:8-15.

43. Rasmussen TE, Clouse WD, Peck MA, et al. Development and implementation of endovascular capabilities in wartime. J Trauma 2008;64:1169-1176. 
44. Beekley AC, Sebesta JA, Blackbourne LH, et al. Prehospital tourniquet use in operation Iraqi Freedom: effect on hemorrhage control and outcomes. J Trauma 2008;64:S28-S37.

45. Kragh JF Jr, Walters TJ, Baer DG, et al. Survival with emergency tourniquet use to stop bleeding in major limb trauma. Ann Surg 2009;249:1-7.

46. Carrel A, Guthrie CC. Uniterminal and biterminal venous transplantations. Surg Gynecol Obstet 1906;2:266-286.

47. Carrel A, Guthrie CC. Anastomosis of blood vessels by the patching method and transplantation of the kidney. JAMA 1906;47:1648-1651.

48. Carrel A. The surgery of blood vessels, etc. Bull Johns Hopkins Hosp 1907;18:18-28.

49. Dente CJ, Feliciano DV. Alexis Carrel (1873-1944) Nobel laureate, 1912. Arch Surg 2005;140:609-610.

50. Cairns H. Vascular aspects of head injuries. Lisboa Med 1942;19:375-410. (Cited by Mulloy JP, et $\mathrm{al}^{51}$ ).

51. Mulloy JP, Flick PA, Gold RE. Blunt carotid injury: a review. Radiology 1998;207:571585.

52. Yamada S, Kindt GW, Youmans JR. Carotid artery occlusion due to nonpenetrating injury. J Trauma 1967;7:333-342.

53. Parmley LF, Mattingly TW, Manion WC, Jahnke EJ Jr. Nonpenetrating traumatic injury of the aorta. Circulation 1958;17:1086-1101.

54. Morris GC Jr, Beall AC Jr, Roof WR, DeBakey ME. Surgical experience with 220 acute arterial injuries in civilian practice. Am J Surg 1960;99:775-781.

55. Taylor H, Williams B. Arteriovenous fistula following disk surgery. Br J Surg 1962;50:47-50. 
56. Pearce CW, McCool E, Schmidt FE. Control of bleeding from cardiovascular wounds: balloon catheter tamponade. Ann Surg 1966;166:257-259.

57. Dotter CT. Transluminally-placed coilspring endarterial tube grafts: long-term patency in canine popliteal artery. Invest Radiol 1969;4:329-332.

58. Friedman SG. Charles Dotter and the fiftieth anniversary of endovascular surgery. J Vasc Surg 2015;61:556-558.

59. Smiley K, Perry MO. Balloon catheter tamponade of major vascular wounds. Am J Surg $1971 ; 121: 326-327$.

60. Mubarak SJ, Owen CA. Double-incision fasciotomy of the leg for decompression in compartment syndromes. J Bone Joint Surg Am 1977;59:184-187.

61. Majeski JA, Gauto A. Management of peripheral arterial vascular injuries with a Javid shunt. Am J Surg 1979;138:324-325.

62. Matsen FA III. Compartmental Syndromes. New York: Grune \& Stratton; 1980.

63. Feliciano DV, Mattox KL, Graham JM, Bitondo CG. Five-year experience with PTFE grafts in vascular wounds. J Trauma 1985;25:71-82.

64. Mattox KL, Feliciano DV, Burch J, et al. Five thousand seven hundred sixty cardiovascular injuries in 4459 patients. Epidemiologic evolution 1958 to 1987. Ann Surg 1989;209:698-707.

65. Frykberg ER, Crump JM, Vines FS, et al. A reassessment of the role of arteriography in penetrating proximity extremity trauma: a prospective study. J Trauma 1989;29:10411052. 
66. Frykberg ER, Dennis JW, Bishop K, et al. The reliability of physical examination in the evaluation of penetrating extremity trauma for vascular injury: results at one year. $\mathrm{J}$ Trauma 1991;31:502-511.

67. Frykberg JT. Arteriography of the injured extremity: are we in proximity to an answer? (Editorial). J Trauma 1992;32:551-552.

68. Dennis JW, Frykberg ER, Crump JM, et al. New perspectives on the management of penetrating trauma in proximity to major limb arteries. J Vasc Surg 1990;11:85-93.

69. Dennis JW, Frykberg ER, Veldenz HC, et al. Validation of nonoperative management of occult vascular injuries and accuracy of physical examination alone in penetrating extremity trauma: 5- to 10-year follow-up. J Trauma 1998;44:243-253.

70. Johansen K, Lynch K, Paun M, Copass M. Non-invasive vascular tests reliably exclude occult arterial trauma in injured extremities. J Trauma 1991;31:515-522.

71. Lynch K, Johansen K. Can Doppler pressure measurement replace "exclusion" arteriography in the diagnosis of occult extremity arterial trauma? Ann Surg $1991 ; 214: 737-741$.

72. Meissner M, Paun M, Johansen K. Duplex scanning for arterial trauma. Am J Surg $1991 ; 161: 552-555$.

73. Bynoe RP, Miles WS, Bell RM, et al. Noninvasive diagnosis of vascular trauma by duplex ultrasonography. J Vasc Surg 1991;14:346-352.

74. Marin ML, Veith FJ, Panetta TF, et al. Percutaneous transfemoral insertion of a stented graft to repair a traumatic femoral arteriovenous fistula. J Vasc Surg 1993;18:299-302.

75. Marin ML, Veith FJ, Panetta TF, et al. Transluminally placed endovascular stented graft repair for arterial trauma. J Vasc Surg 1994;20:466-473. 
76. Marin ML, Veith FJ, Cynamon J, et al. Initial experience with transluminally placed endovascular grafts for the treatment of complex vascular lesions. Ann Surg $1995 ; 222: 449-469$.

77. Pate JW, Fabian TC, Walker W. Traumatic rupture of the aortic isthmus: an emergency? World J Surg 1995;19:119-125.

78. Fabian TC, Richardson D, Croce MA, et al. Prospective study of blunt aortic injury: multicenter trial of the American Association for the Surgery of Trauma. J Trauma 1997;42:374-383.

79. Kato N, Dake MD, Miller DC, et al. Traumatic thoracic aortic aneurysm: treatment with endovascular stent-grafts. Radiology 1997;205:657-662.

80. Semba CP, Kato N, Kee ST, et al. Acute rupture of the descending thoracic aorta: repair with use of endovascular stent-grafts. JVIR 1997;8:337-342.

81. Soto JA, Munera F, Carodoso N, et al. Diagnostic performance of helical CT angiography in trauma to large arteries of the extremities. J Comput Assist Tomogr 1999;23:188-196.

82. Soto JA, Munera F, Morales C, et al. Focal arterial injuries of the proximal extremities: helical CT arteriography as the initial method of diagnosis. Radiology 2001;218:188-194.

83. Biffl WL, Moore EE, Offner PJ, et al. Blunt carotid arterial injuries: implications of a new grading scale. J Trauma 1999;47:84-5853.

84. Biffl WL, Moore EE, Offner PJ, et al. Optimizing screening for blunt cerebrovascular injuries. Am J Surg 1999;178:517-522.

85. Miller PR, Fabian TC, Croce MA, et al. Prospective screening for blunt cerebrovascular injuries. Analysis of diagnostic modalities and outcomes. Ann Surg 2002; 236:386-395. 
86. Morozumi J, Ohta S, Homma H, et al. Introduction of mobile angiography into the trauma resuscitation room. J Trauma 2009;67:245-251.

87. Demetriades D, Velmahos GC, Scalea TM, et al. Blunt traumatic thoracic aortic injuries: early or delayed repair - results of an American Association for the Surgery of Trauma prospective study. J Trauma 2009;66:967-973.

88. Shackford SR, Kahl JE, Calvo RY, et al. Limb salvage after complex repairs of extremity arterial injuries is independent of surgical specialty training. J Trauma Acute Care Surg 2013;74:716-724.

89. Feliciano DV, Cruse PA, Burch JM, Bitondo CG. Delayed diagnosis of arterial injuries. Am J Surg 1987;154:579-584.

90. Turcotte JK, Towne JB, Bernhard VM. Is arteriography necessary in the management of vascular trauma of the extremities? Surgery 1978;84:557-562.

91. Wind GG, Valentine JR, eds. Axillary artery. In Wind GG, Valentine RJ, eds. Anatomic Exposures in Vascular Surgery. $3^{\text {rd }}$ ed. Philadelphia: Lippincott Williams \& Wilkins (Wolters Kluwer); 2013:155-175.

92. O'Gorman RB, Feliciano DV. Arteriography performed in the emergency center. Am J Surg 1986;152:323-325.

93. Monson DO, Saletta JD, Freeark RJ. Carotid vertebral trauma. J Trauma 1969;9:987-999.

94. Larsen PE, Smead WL. Vertical ramus osteotomy for improved exposure of the distal internal carotid artery: a new technique. J Vasc Surg 1992;15:226-231.

95. Fisher DF, Clagett GP, Parker JI, et al. Mandibular subluxation for high carotid exposure. J Vasc Surg 1984;1:727-733. 
96. Jaspers GW, Witjes MJ, van den Dungen JJ, et al. Mandibular subluxation for distal internal carotid artery exposure in edentulous patients. J Vasc Surg 2009;50:1519-1522.

97. Vikatmaa P, Mäkitie AA, Railo M, et al. Midline mandibulotomy and interposition grafting for lesions involving the internal carotid artery below the skull base. J Vasc Surg 2009;49:86-92.

98. Ball CG, Wyrzkowski AD, Nicholas JM, et al. A decade's experience with balloon catheter tamponade for the emergency control of hemorrhage. J Trauma 2011;70:330333.

99. Subramanian A, Vercruysse G, Dente C, et al. A decade's experience with temporary intravascular shunts at a civilian level I trauma center. J Trauma 2008;65:316-326.

100. Feliciano DV, Subramanian A. Temporary vascular shunts. Eur J Trauma Emerg Surg 2013;39:553-560.

101. Hancock H, Rasmussen TE, Walker AJ, Rich NM. History of temporary intravascular shunts in the management of vascular injury. J Vasc Surg 2010;52:1405-1409.

102. Rich NM, Hughes CW, Baugh JH, Management of venous injuries. Ann Surg 1970;171:724-730.

103. Sullivan WG, Thornton FH, Baker LH, et al. Early influence of popliteal vein repair in the treatment of popliteal vessel injuries. Am J Surg 1971;122:528-531.

104. Hobson RW II, Howard EW, Wright CB, et al. Hemodynamics of canine femoral venous ligation: significance in combined arterial and venous injuries. Surgery 1973;74:824-829.

105. Rich NM, Collins GJ Jr, Andersen CA, McDonald PT. Autogenous venous interposition grafts in repair of major venous injuries. J Trauma 1977;17:512-520. 
106. Pasch AR, Bishara RA, Schuler JJ, et al. Results of venous reconstruction after civilian vascular trauma. Arch Surg 1986;121:607-611.

107. Parry NG, Feliciano DV, Burke RM, et al. Management and short-term patency of lower extremity venous injuries with various repairs. Am J Surg 2003;186:631-635.

108. Mullins RJ, Lucas CE, Ledgerwood AM. The natural history following venous ligation for civilian injuries. J Trauma 1980;20:737-743.

109. Timberlake GA, O'Connell RC, Kerstein MD. Venous injury: to repair or ligate, the dilemma. J Vasc Surg 1986;4:553-558.

110. Yelon JA, Scalea TM. Venous injuries of the lower extremities and pelvis: repair versus ligation. J Trauma 1992;33:532-538.

111. Kurtoglu M, Yanar H, Taviloglu K, et al. Serious lower extremity venous injury management with ligation: prospective overview of 63 patients. Am Surg 2007;73:10391043.

112. Feliciano DV. Heroic procedures in vascular injury management. The role of extraanatomic bypasses. Surg Clin North Am 2002;82:115- 124.

113. Feliciano DV, Accola KD, Burch JM, Spjut-Patrinely V. Extraanatomic bypass for peripheral arterial injuries. Am J Surg 1989;158:506-510.

114. Stain SC, Weaver FA, Yellin AE. Extra-anatomic bypass of failed traumatic arterial repairs. J Trauma 1991;31:575-578.

115. Dente CJ, Wyrzykowski AD, Feliciano DV. Fasciotomy. Curr Prob Surg 2009;46:769840.

116. Coughlin PA, Mavor AID. Arterial consequences of recreational drug use. Eur J Vasc Endovasc Surg 2006; 32:389-396. 
117. Taghi Salehian M, Shahid N, Mohseni M, et al. Treatment of infected pseudoaneurysm in drug abusers: ligation or reconstruction. Arch Iranian Med 2006; 9:49-52

118. Georgiadis GS, Lazarides MK, Polychronidis A, Simopoulos C. Surgical treatment of femoral artery infected false aneurysms in drug abusers. ANZ J Surg 2005: 75:10051010.

119. Ting ACW, Cheng SWK. Femoral pseudoaneurysms in drug addicts. World J Surg 1997;21:783-787. 
Table 1. Military Contributions to and Documentors of the Management of Vascular Trauma

\begin{tabular}{|c|c|c|}
\hline First author by war & Year & Contribution(s) \\
\hline \multicolumn{3}{|l|}{ World War I } \\
\hline Soubbotitch $^{16}$ & 1913 & Repair or ligation of vascular injuries \\
\hline Taylor $^{17}$ & 1916 & $\begin{array}{l}\text { Sequential "artery forceps" to control perforated } \\
\text { or lacerated IVC }\end{array}$ \\
\hline Weglowski $^{18,19}$ & $\begin{array}{l}\text { Cited by others: } \\
1985,1987\end{array}$ & Repair or ligation of arterial injuries \\
\hline Makins $^{20}$ & 1919 & Gunshot Injuries to the Blood Vessels \\
\hline World War II & & \\
\hline Blakemore $^{21}$ & 1942 & Vitallium tube to artery \\
\hline DeBakey $^{22}$ & 1946 & 2,471 arterial injuries \\
\hline Barr $^{23}$ & 2016 & Review of DeBakey \\
\hline Elkin $^{24}$ & 1946 & Resection of clavicle for exposure \\
\hline Shumacker, Jr ${ }^{25}$ & 1948 & Exposure of mediastinal vessels \\
\hline Elkin $^{26}$ & 1955 & Vascular Surgery in World War II \\
\hline \multicolumn{3}{|l|}{ Korean War } \\
\hline Ziperman $^{27}$ & 1954 & Epidemiology of arterial injuries \\
\hline Hughes $^{28}$ & 1954 & Aortic balloon catheter \\
\hline Hughes $^{29}$ & 1958 & 304 arterial injuries \\
\hline Spencer $^{30,31}$ & 1955,2006 & 97 arterial injuries \\
\hline Howard $^{32}$ & 1958 & Battle Casualties in Korea \\
\hline Howard $^{33}$ & 1998 & Late reminiscence \\
\hline \multicolumn{3}{|l|}{ Vietnam War } \\
\hline Rich $^{13,34,35}$ & 1969,2017 & Vietnam Vascular Registry \\
\hline Hata $^{36}$ & 2016 & Vietnam Vascular Registry \\
\hline Rich $^{37-39}$ & 1970 & 1,000 arterial injuries \\
\hline $\operatorname{Rich}^{40}$ & 1978 & Vascular Trauma \\
\hline Israel-Egypt, etc War & & \\
\hline Eger $^{41}$ & 1971 & Temporary shunts in arteries \\
\hline \multicolumn{3}{|l|}{$\begin{array}{l}\text { Operation Iraqi } \\
\text { Freedom }\end{array}$} \\
\hline Rasmussen $^{42}$ & 2006 & Temporary shunts in vessels \\
\hline Rasmussen $^{43}$ & 2008 & Endovascular capabilities in wartime \\
\hline Beekley $^{44}$ & 2008 & Pre-hospital tourniquet use \\
\hline Kragh, Jr ${ }^{45}$ & 2009 & Pre-hospital tourniquet use \\
\hline
\end{tabular}

Titles of books are in italics. 
Table 2. Civilian Contributions to and Documentors of the Management of Vascular Trauma

\begin{tabular}{|c|c|c|}
\hline First author & Year & Contribution(s) \\
\hline Carrel $^{46-48}$ & 1906,1907 & $\begin{array}{l}\text { Triangulation for end-to-end anastomosis; end-to-side } \\
\text { anastomosis; interposition vein graft; patch technique to } \\
\text { encompass branches }\end{array}$ \\
\hline Dente $^{49}$ & 2005 & Alexis Carrel (1873-1944) Nobel Laureate, 1912 \\
\hline Cairns ${ }^{50}$ & 1942 & BCAI \\
\hline Mulloy $^{51}$ & 1998 & BCAI \\
\hline Yamada $^{52}$ & 1967 & Review of BCAI \\
\hline Parmley ${ }^{53}$ & 1958 & Nonpenetrating aortic rupture \\
\hline Morris, $\mathrm{Jr}^{54}$ & 1960 & First large report of civilian arterial injuries \\
\hline Taylor $^{55}$ & 1962 & Balloon tamponade for iatrogenic vascular injury \\
\hline Pearce $^{56}$ & 1966 & Balloon tamponade for injured right pulmonary artery \\
\hline Dotter $^{57}$ & 1969 & Laboratory origin of endovascular stents \\
\hline Friedman $^{58}$ & 2015 & Laboratory origin of endovascular stents \\
\hline Smiley $^{59}$ & 1971 & Balloon tamponade for abdominal vascular injury \\
\hline Mubarak $^{60}$ & 1977 & Double-incision 4-compartment fasciotomy \\
\hline Majeski $^{61}$ & 1979 & Temporary shunts in arteries \\
\hline Matsen III ${ }^{62}$ & 1980 & Compartmental Syndromes \\
\hline Feliciano $^{63}$ & 1985 & PTFE grafts in vascular injuries \\
\hline Mattox $^{64}$ & 1989 & 5,670 cardiovascular injuries at one center \\
\hline Frykberg $^{65-67}$ & $\begin{array}{l}1989,1991, \\
1992\end{array}$ & Reliability of exam in diagnosing arterial injuries \\
\hline Dennis $^{68,69}$ & 1990,1998 & Nonoperative management of occult arterial injuries \\
\hline Johansen $^{70}$ & 1991 & Doppler arterial pressure index $<0.9$ \\
\hline Lynch $^{71}$ & 1991 & Doppler arterial pressure index $<0.9$ \\
\hline Meissner $^{72}$ & 1991 & Duplex ultrasonography for arterial injury \\
\hline Bynoe $^{73}$ & 1991 & Duplex ultrasonography for arterial injury \\
\hline Marin $^{74-76}$ & $\begin{array}{l}1993, \\
1994,1995 \\
\end{array}$ & Endostent grafts for arterial injuries (not thoracic aorta) \\
\hline Pate $^{77}$ & 1995 & Beta blockers for blunt aortic injury \\
\hline Fabian $^{78}$ & $1997 \times-2$ & Multicenter review of blunt aortic injury \\
\hline Kato $^{79}$ & 1997 & Endostent graft into blunt aortic injury \\
\hline Semba ${ }^{80}$ & 1997 & Endostent graft into blunt aortic injury \\
\hline Soto $^{81,82}$ & 1999,200 & CT arteriography for extremity arterial injury \\
\hline Biffl $^{83}$ & 1999 & Grading scale for BCAI \\
\hline Biffl $^{84}$ & 1999 & Denver Health screening for BCAI \\
\hline Miller $^{85}$ & 2002 & University of Tennessee screening for BCAI \\
\hline Morizumi $^{86}$ & 2009 & Mobile angiography in trauma room \\
\hline Demetriades $^{87}$ & 2009 & Multicenter review of blunt aortic injury \\
\hline Shackford $^{88}$ & 2013 & Multicenter review of surgical specialty in limb salvage \\
\hline
\end{tabular}

Titles of books are in italics.

BCAI, blunt carotid artery injury; PTFE, polytetrafluoroethylene. 
Table 3. Indications for Insertion of a Temporary Intraluminal Vascular Shunt

\begin{tabular}{|l|}
\hline $\begin{array}{l}\text { Complex repair of the internal carotid artery in Zone III of } \\
\text { the neck (from the angle of the mandible to the base of the } \\
\text { skull) }\end{array}$ \\
\hline Gustilo IIIC open fracture of an extremity \\
\hline $\begin{array}{l}\text { Need for perfusion as a complex revascularization after } \\
\text { trauma is performed }\end{array}$ \\
\hline $\begin{array}{l}\text { Perfusion of an amputated part of an upper extremity prior } \\
\text { to replantation }\end{array}$ \\
\hline "Damage control" for the patient with near exsanguination \\
from a peripheral vascular injury \\
\hline "Damage control" for the patient with multiple intra- \\
abdominal injuries including an abdominal vascular injury, \\
a complex abdominal vascular injury, or near- \\
exsanguination from a truncal vascular injury \\
\hline "Damage control" for the patient with a cervical, truncal, or \\
peripheral vascular injury and a surgical team with an \\
overwhelming number of casualties, limited resources, or \\
limited operative experience with vascular injuries (military \\
triage)
\end{tabular}

See reference 101 for more information. 
Table 4. Indications for Performing an Extra-Anatomic Vascular Bypass in an Extremity

\begin{tabular}{|l|}
\hline Loss of soft tissue over injured artery or vein \\
\hline $\begin{array}{l}\text { Postoperative infection of the incision with blowout of } \\
\text { underlying arterial repair }\end{array}$ \\
\hline $\begin{array}{l}\text { Infections in both soft tissue and underlying native artery } \\
\text { secondary to injection of illicit drugs }\end{array}$ \\
\hline
\end{tabular}

See references 113-115 for more information. 


\section{FIGURE LEGENDS}

Figure 1. Late pseudoaneurysm and arteriovenous fistula 3 weeks after "negative" exploration of the left axillary artery. The exploration by an inexperienced surgical team was hindered by the muscular habitus of the patient and the failure to detach the origin of the pectoralis minor muscle. (Reprinted from Feliciano DV. Vascular Trauma. In: Levine BM, Copeland EM III, Howard JR, Sugerman HJ, Warshaw AL, eds. Current Practice of Surgery. New York: Churchill Livingstone; 1993, with permission from Elsevier.)

Figure 2. Foley (through external auditory canal) and Fogarty (through internal carotid artery) balloon catheter tamponade after stab wound to internal carotid artery in Zone III of left neck.

Figure 3. Saphenous vein graft in superficial femoral artery and 10-mm ringed PTFE graft in femoral vein. (Reprinted from Feliciano DV. Peripheral vasculature. In: Britt LD, Trunkey DD, Feliciano DV, eds. Acute Care Surgery. Principles and Practice. New York: Springer; 2007, with permission from Springer.)

Figure 4. Full range of motion of the right elbow 22 months after blowout of an exposed brachial artery. PTFE suture line and replacement with an extra-anatomic saphenous vein bypass graft (marked with black lines on skin). (Reprinted from Feliciano ${ }^{112}$ with permission from Elsevier.)

Figure 5. Proximal aspect of skin incision used in volar-ulnar approach to decompress the volar and lateral compartments of the forearm. (Reprinted from Dente and colleagues ${ }^{115}$ with permission from Elsevier.) 
Figure 6. Infected false aneurysm of the left common femoral artery. The patient had a history of repeated injections of heroin into the left groin. Presumably, some injections were into the left common femoral artery. 


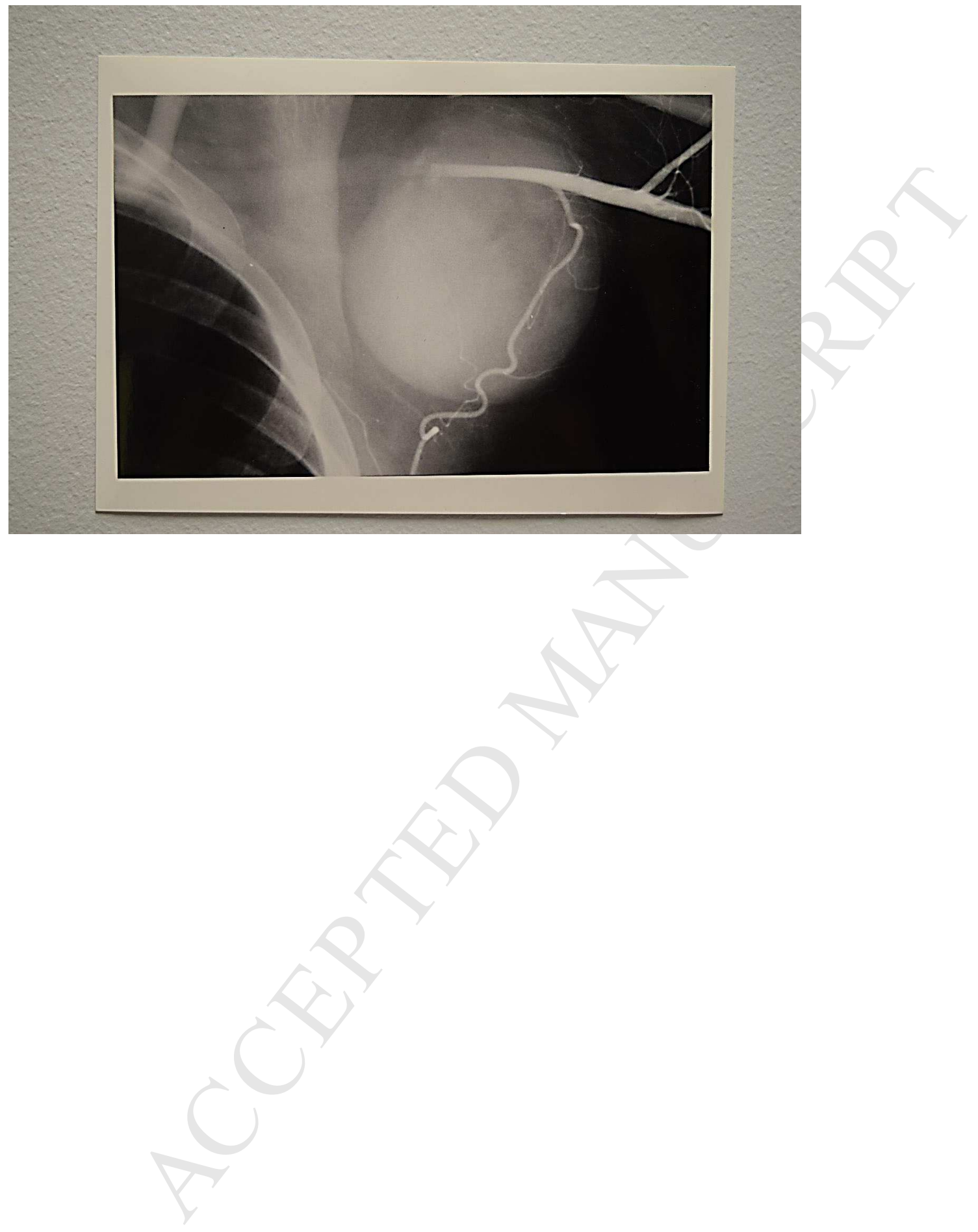




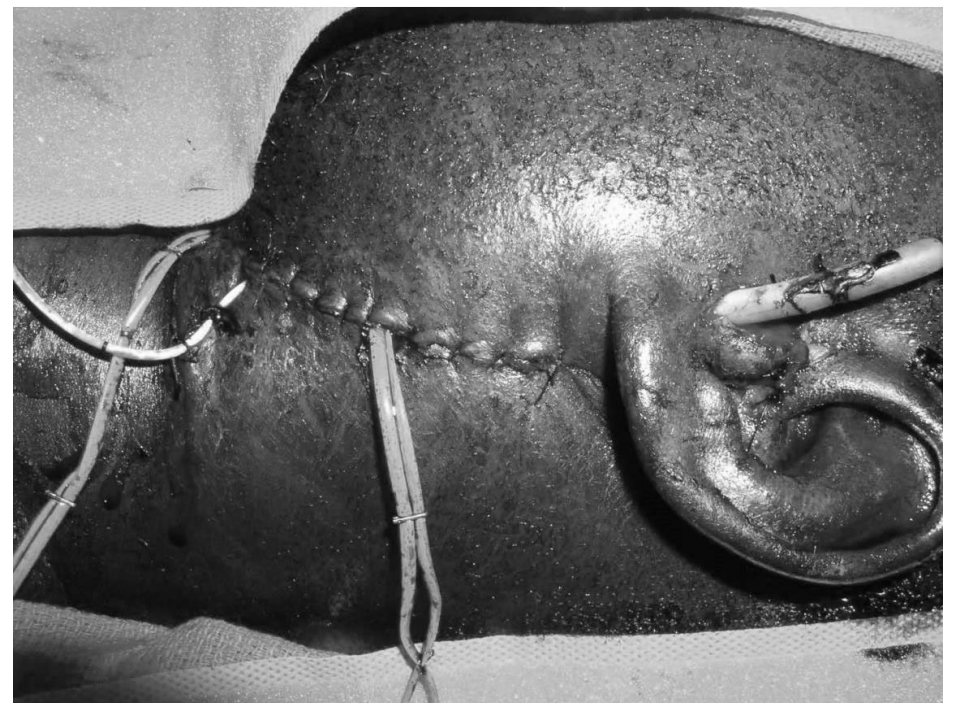




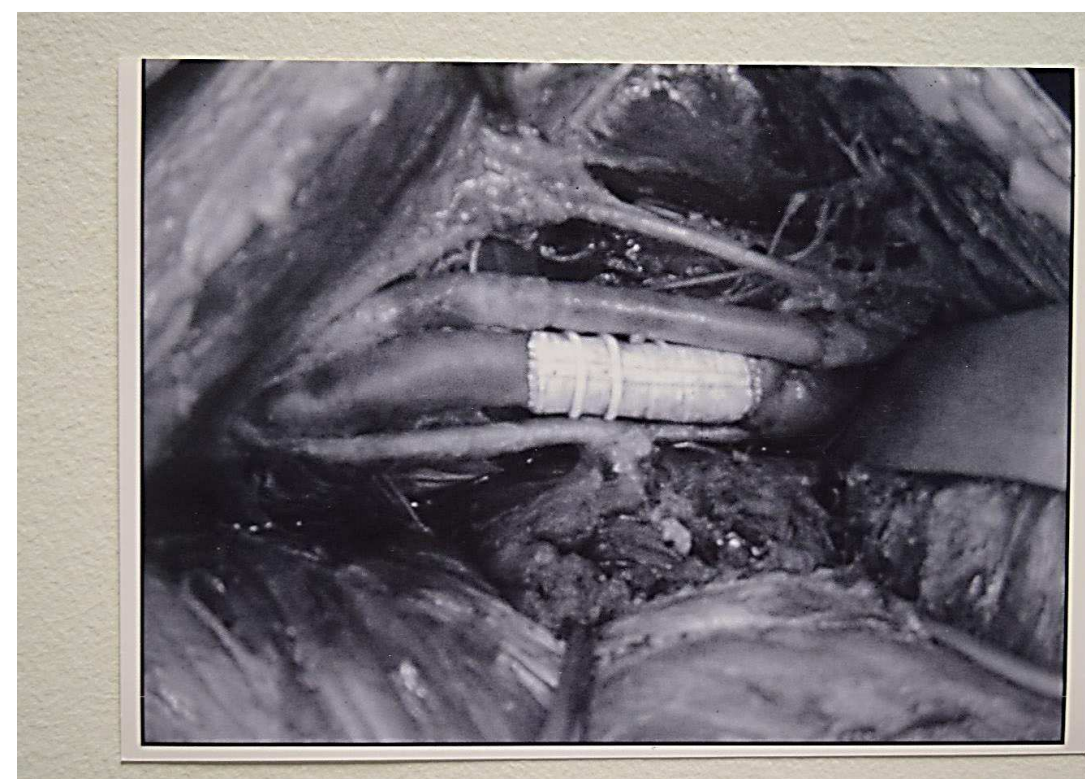



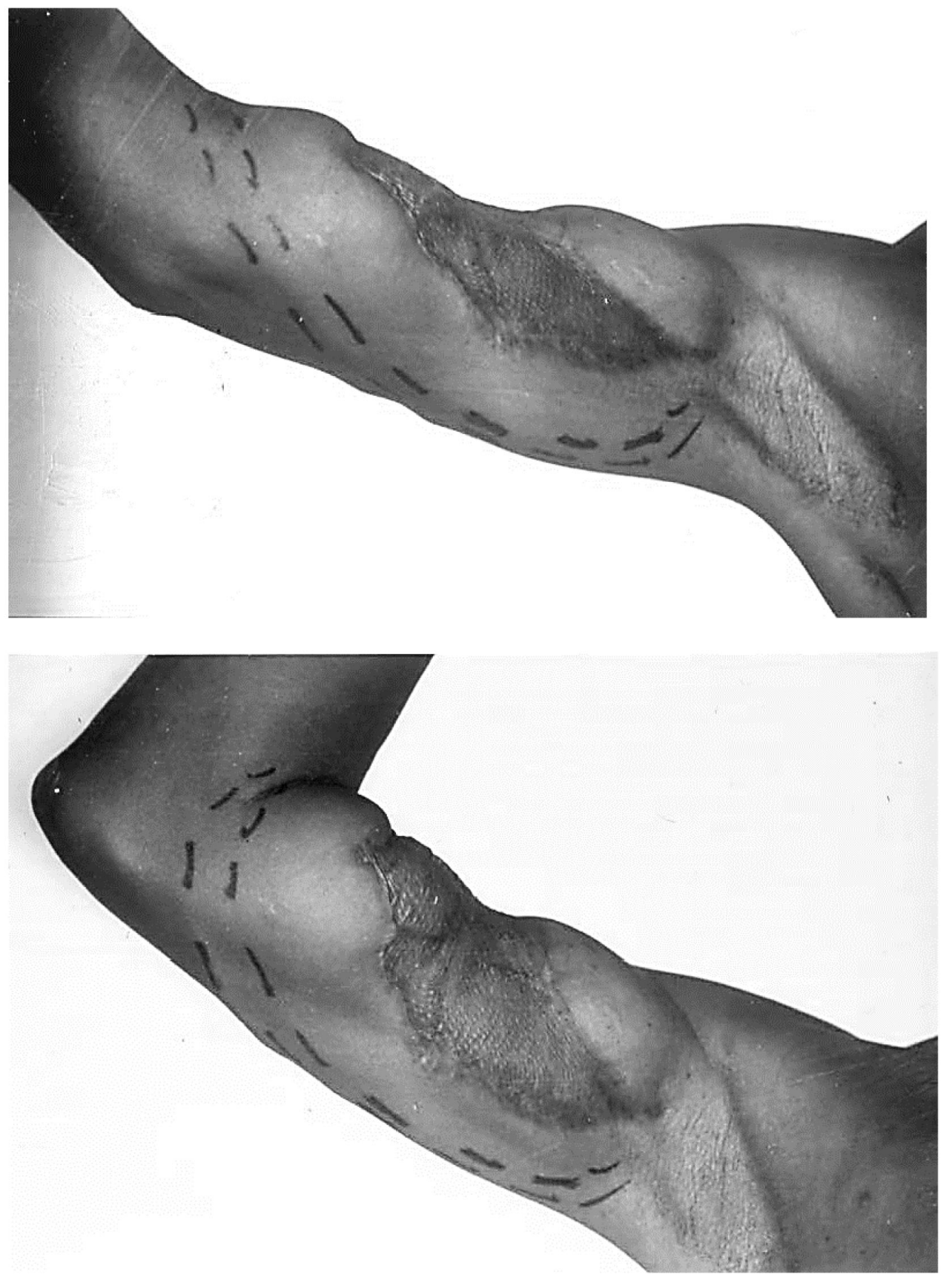


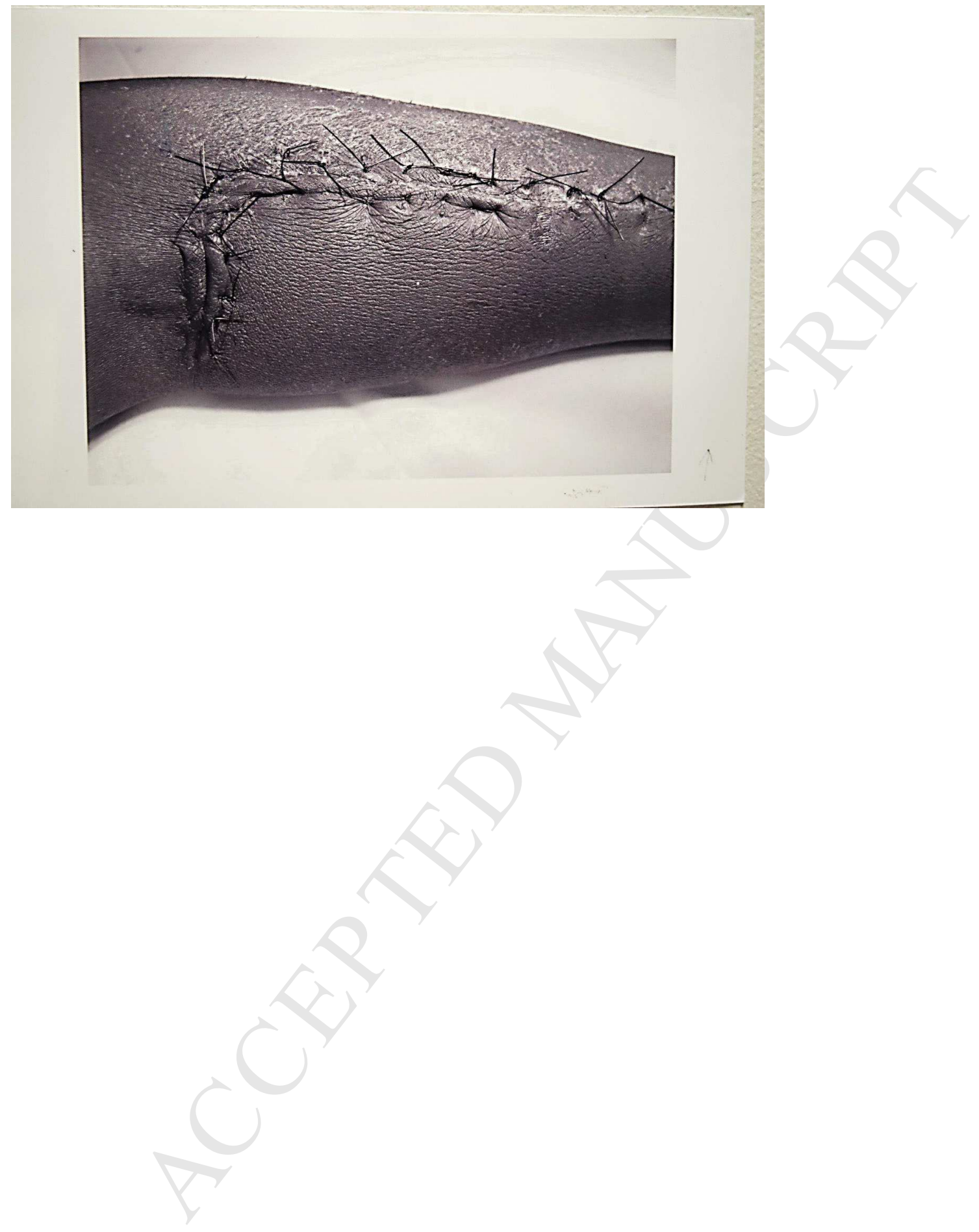




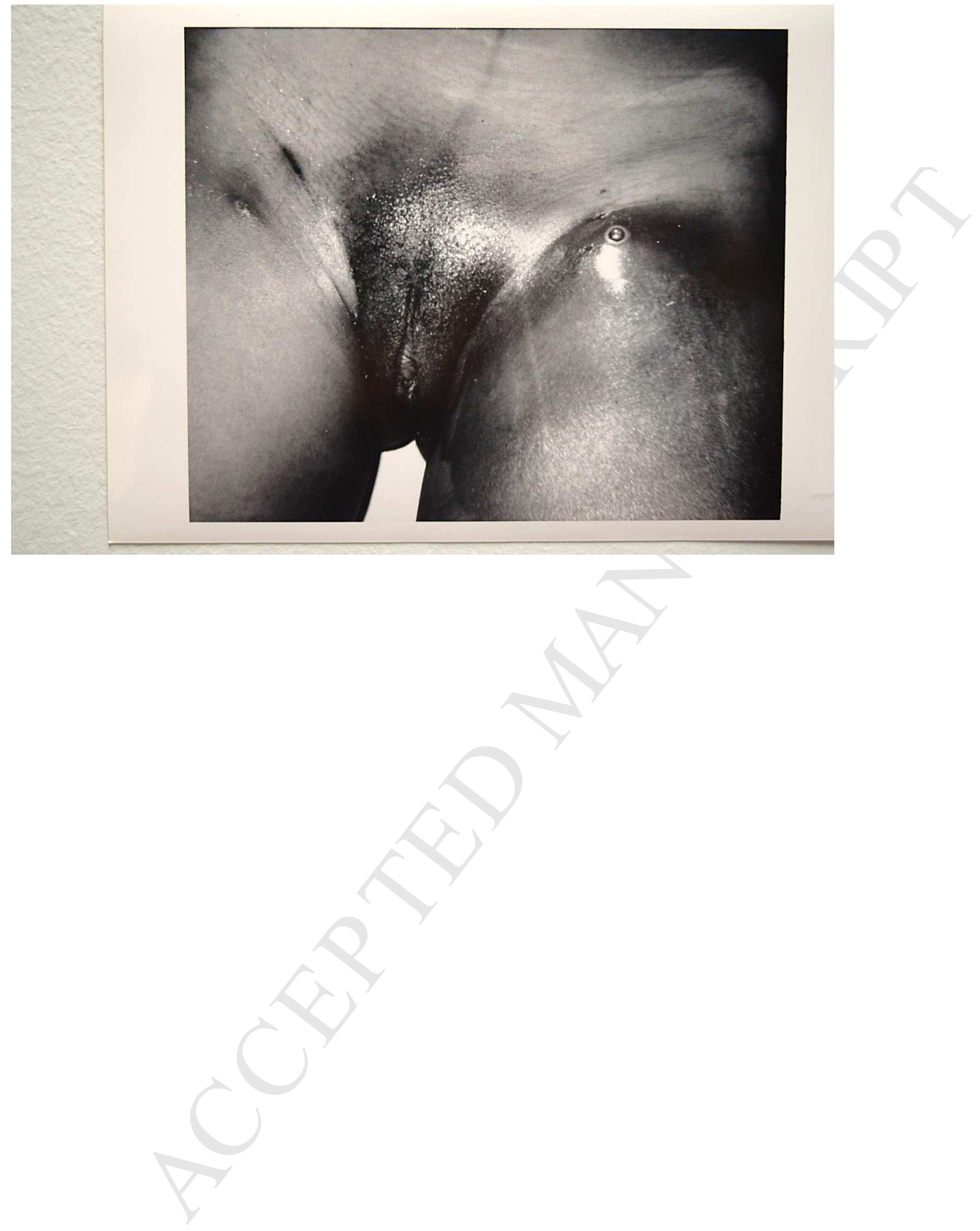

